The Mixed Economy of Support for the Aged in Australia:

\title{
Lessons for Privatisation
}

\section{Author/Contributor:}

Saunders, Peter; Fine, Michael

\section{Publication details:}

Working Paper No. 36

SPRC Discussion Paper

0733403123 (ISBN)

1447-8978 (ISSN)

\section{Publication Date:}

1992

\section{DOI:}

https://doi.org/10.26190/unsworks/172

\section{License:}

https://creativecommons.org/licenses/by-nc-nd/3.0/au/

Link to license to see what you are allowed to do with this resource.

Downloaded from http://hdl.handle.net/1959.4/33956 in https:// unsworks.unsw.edu.au on 2023-04-26 


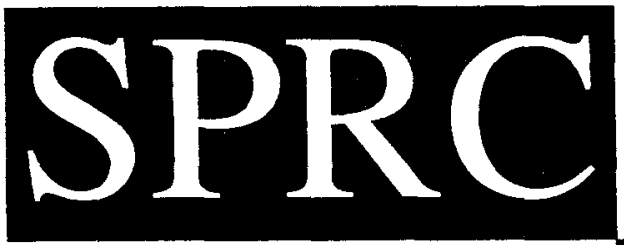

\section{Discussion Papers}

\section{The Mixed Economy of Support for the Aged in Australia: Lessons for Privatisation}

by

Peter Saunders and Michael Fine

THE UNIVERSITY OF NEW SOUTH WALES PO BOX 1. KENSINGTON. NEW SOUTH WALES . AUSTRALIA. 2033 
The Social Policy Research Centre (formerly the Social Welfare Research Centre) was established in January 1980 under an Agreement between the University of New South Wales and the Commonwealth Government. In accordance with the Agreement the Centre is operated by the University as an independent unit within the University. The Director of the Centre is responsible to the Vice-Chancellor and receives advice in formulating the Centre's research agenda from a Management Board.

SOCIAL POLICY RESEARCH CENTRE DISCUSSION PAPERS are intended as a forum for the publication of selected research papers on research within the Centre, or commissioned by the Centre, for discussion and comment in the research community and/or welfare sector prior to more formal publication. Limited copies of each DISCUSSION PAPER will be available on a first-come, first-served basis from the Publications and Information Officer, Social Policy Research Centre, University of New South Wales, P O Box 1, Kensington, NSW 2033 [tel: (02) 697 3857]. A full list of DISCUSSION PAPERS can be found at the back of this DISCUSSION PAPER.

As with all of the Centre's publications, the views expressed in this DISCUSSION PAPER do not reflect any official position on the part of the Centre.

Anthony King

Editor 


\title{
The Mixed Economy of Support for the Aged in Australia: Lessons for Privatisation
}

\author{
Peter Saunders and Michael Fine
}

ISSN 10372741

ISBN 0733403123

This is a revised version of a paper initially presented at the Seminar on International Theory and Practice of Privatisation, University of New South Wales, 24 July 1992. The paper is shortly to be published in The Economic and Industrial Relations Review. The authors wish to thank Sara Graham and Mark Lyons for their comments on the earlier version of the paper, but are responsible for any errors of fact or interpretation. 


\begin{abstract}
This paper describes and analyses aspects of Australian income support and service arrangements for the aged in the context of broader issues relating to privatisation. It is argued that much of the welfare privatisation debate is overly simplistic and does not recognise the important role which the nongovernment sector already plays in both aspects of support for the aged. Analysis of income data shows, for example, that transfer income currently accounts for less than half of the income of the aged. The trend towards superannuation is apparent in the data, although some doubts are raised about the impact of superannuation expansion on the implications for the costs of retirement income support of population ageing. In the area of community services, the paper describes the development of policy over the last few decades in order to illustrate the complexity of existing arrangements. The switch from institutional to community care is identified as a major trend, particularly during the $1980 \mathrm{~s}$, and some of the implications of this development for privatisation are drawn out and analysed.
\end{abstract}




\section{Introduction}

The welfare privatisation debate in Australia has been dominated by considerations of choice, competition, consumer rights and cost. Much of the rhetoric has emphasised the need to re-think traditional forms of welfare provision and finance in ways which increase competition in service provision and delivery mechanisms thereby increasing efficiency and expanding the range of choices available to users. Underlying the rhetoric is the vision of an economic model of competitive suppliers meeting the needs of fully informed, freely choosing consumers, both responding to price signals that guide the efficient allocation of scarce resources through the invisible hand of market competition. In practice, however, issues of choice, competition and consumer rights have generally taken second place to cost considerations, specifically those relating to the cost to government of welfare programs. Public budgets have been constrained throughout the industrialised world since the mid-seventies and in almost all countries the ratio of government outlays to GDP began to decline during the eighties - a significant departure from the consistent upward trend of the previous three decades (Saunders, 1992).

The specific policy context addressed in this paper relates to the role of government in the finance and provision of income support and community care services for the aged. Demographic change projected for the coming decades indicates that cost pressures will intensify, even if current levels of provision remain unaltered. Such cost projections are likely to be further exacerbated as the projected demographic changes tilt the balance of political power in favour of the increasing proportion of the population and, more important, the electorate - who are elderly or close to retirement age. Mindful of these developments, successive Australian governments have been reassessing the balance between the public and private sectors in their policies for the aged. Superannuation has been an on-going area of intense policy reform over the last decade and reforms in residential and community care policies for the aged have been as significant, if generally less publicised.

Given the scope and importance of the underlying theoretical and conceptual issues, as well as the more practical concerns surrounding policy 
administration and service delivery, it is necessary to adopt a somewhat selective approach, focusing on a number of policy developments in support for the aged which we believe contain lessons of more general relevance to the welfare privatisation debate. We begin, in Section 2, by outlining a taxonomy of privatisation which embodies a simple conceptual framework. Some of the limitations of the framework are then enumerated in the context of how policies for the aged actually operate in practice. Section 3 deals with income support for the aged and contains an analysis of recent changes in the income sources of successive cohorts of retired people which serves to put the issue in perspective. The role of occupational superannuation in privatising income support for the elderly is then briefly assessed. Section 4 focuses on the development of residential care and community support policies over the last four decades, the changing shape of Australia's aged care policies over the eighties and the issues to which those changes have given rise. The main lessons from this brief overview are drawn together in Section 5.

\section{Welfare Privatisation: A Conceptual Overview}

Privatisation is often discussed as if it is an objective of policy. Politicians talk of privatisation in such terms, even if as an intermediate policy objective, a means of achieving the ultimate objectives of improved effectiveness and efficiency. Reductions in government spending and the size of the public sector are also objectives of privatisation, though less explicitly considered as such. Privatisation is, however, best analysed in the social welfare context as a process rather than a policy objective as such. This implies that, as with other policy processes of government, the final outcome will depend upon the reactions and impacts of the various actors and interest groups associated with the design, implementation and administration of the policy. Governments rarely have the ability or the will to push through policy reforms which take no account of such reactions and there is already an abundance of evidence illustrating how the initial aims of welfare privatisation moves become diluted and diverted during the subsequent politics of the policy reform process.

Following Walker (1984), welfare privatisation can be defined in the following terms: 
Privatisation represents the introduction or further extension of market principles in the public social services ... Privatisation may be said to take place when responsibility for a service or a particular aspect of service delivery passes, wholly or in part, to the private sector and when market criteria, such as profit or ability to pay, are used to ration or distribute benefits and services. (Walker, 1984: 25)

Privatisation is thus a process in which the balance between public and private sectors in welfare involvement is altered in such a way that the role of either conventional market forces or of private institutions increases. Changing the public-private mix is not, of itself, evidence of privatisation since it may simply reflect the reduction or abandonment of government programs. To be considered as privatisation, governments must actively encourage an expanded role for the private sector or for market forces. It is worth giving emphasis to two points about this definition at this stage: first, there is no implication that privatisation will necessarily involve reduced government expenditure; second, even if government spending is reduced, other forms of government intervention may expand as the increased role of private sector involvement is encouraged.

It is important to emphasise that it is misleading and simplistic to couch the discussion of privatisation in terms of a simple and straightforward dichotomy between the public and private sectors, or between the state and the market. The Australian welfare system, like that in all other OECD countries (though more so here than in most) is best described as a mixed economy of welfare in which public and private sectors both play significant roles in welfare provision, finance and delivery (O'Connor, 1990). It is thus critical to understand how the various elements in the mixed economy of welfare interact and influence each other in the process of advancing the well-being of citizens. In order to achieve this, it is necessary to identify the various forms of public and private activity in somewhat more detail.

The public sector is multi-dimensional, in regard to both scope and purpose. Following Le Grand and Robinson (1984) one can distinguish three main types of activity: public provision, public subsidy and public regulation. Similarly, the private sector (defined here to include everthing which is not part of the public sector) embodies an enormous range of institutions and activities including, in the welfare field, private profit-making commercial 
concerns, non-government (and non-profit) welfare and community organisations, charitable concerns, community collectives, clubs, neighbourhood groups, and individuals themselves acting alone or with the help of family or friends. Each element plays its part in enhancing the welfare of individuals, even though most conventional accounts of the welfare state focus on that sub-set which is subject to direct government intervention of one form or another. The welfare state is thus only one element of what is already, and has for long been, a heavily privatised overall welfare system. ${ }^{1}$ The finance of welfare also embodies a broad spectrum of arrangements, ranging from direct tax finance to indirect ( $\operatorname{tax}$ expenditure) finance by the government, through to revenue generated from user charges and unpaid voluntary or domestic labour.

Despite this diversity, proponents of privatisation tend to equate the private (non-government) sector with the market (for-profit) sector and argue that privatisation will automatically bring with it all of the economic benefits normally associated with market-driven allocative processes. This is not the place to argue the relative merits of bureaucratic and market models of allocation, but a couple of points are worth emphasising. The two conditions necessary for market-based systems to produce efficiency gains are competition amongst profit-maximising suppliers and the existence of informed, rational choices by consumers. Without the former, privatisation is likely to replace public monopoly provision by private monopolistic suppliers. Without the latter, privatisation will lead to service duplication and an allocation of resources which is likely to be less, not more, efficient. Perhaps a more fundamental point, however, is that welfare privatisation may involve no increase in the role of market forces as conventionally conceived. What is more likely is the (complete or partial) replacement of government provision or subsidy by an increased role for voluntary agencies or the family. In such instances, the alleged benefits of market forces have nothing to do with shaping the consequences of such changes.

1 Cox (1992a) has recently emphasised this point, arguing that: 'Even today, private expenditure with a welfare purpose (including savings and transfers to relatives) is probably more important than government expenditure on social security and welfare' (Cox, 1992a: 13). See also Cox (1992b) for a fuller account of the evidence in support of this view. 
Privatisation of welfare has received considerable attention from both the right and the left, the former attracted by its emphasis on notions of liberty and competition, and the latter by its potential to advance moves towards decentralisation and the empowerment of consumers. In this latter context, it is useful to consider whether user charges have the potential to do as much to enhance user rights as the introduction of formal rules designed to ensure service quality and protect the rights of consumers of community services. The requirement to pay for something brings with it a certain legitimacy and status which in turn carries the right to voice objections if the service provided is not satisfactory. That right can have more impact if the price paid translates directly into the income of the supplier (rather than offsetting a government grant), who then has an incentive to respond to it. In contrast, where services are 'free', users often feel that to complain is to take unfair advantage of the willingness and support of others. Free services may thus not help to advance consumers' rights. In research undertaken at the Social Policy Research Centre, we have found instances where user charges appear to encourage consumers to voice their concerns and criticisms and others where they do not (Fine, 1992). What is needed here is less emphasis on user charges as a source of revenue for suppliers (or the government) and more research into which of the alternative ways of implementing user charges best enhances the rights of users and how to best offset their adverse distributional consequences.

As noted earlier, public intervention in the welfare area is generally multidimensional, as is private sector involvement. A useful, if limited, framework for recognising the significance of this in the privatisation context was provided in an early analysis of health care privatisation in the United Kingdom by Klein (1984). The framework distinguishes between public and private sector involvement in (a) the provision and (b) the finance of services (and income support). Privatisation represents a movement away from the situation where both finance and provision are by the public sector to any other situation. Klein's basic framework has been employed by Le Grand $(1990 ; 1992)$ to argue that welfare privatisation in the United Kingdom during the 1980s has been characterised by the privatisation of the provision of still predominantly publicly financed services. Any application of Le Grand's analysis to Australia has to recognise that the non-government sector has always played a far greater role in service provision in Australia than it has in Britain. Notwithstanding 
this, there are lessons for Australia from recent attempts in Britain to improve efficiency in service provision and delivery through the use of quasi-market mechanisms (Le Grand, 1991). ${ }^{2}$

Other British writers - notably O'Higgins (1981) and, more recently, Bradshaw (1991) - have pointed to significant privatisation of both the finance and provision of income support in the areas of sickness benefits, maternity allowance and pensions. These studies of actual attempts at welfare privatisation further highlight the limitations of Klein's simplified framework. Analysis of the process of privatisation shows how moves by government meet resistance which deflects and weakens their initial intent and often reduces or removes entirely any reductions in the cost to taxpayers. Thus Bradshaw in his recent account of social security under the Thatcher Government notes that the transfer to employers of responsibility for sickness benefits and maternity allowance was (until 1991) purely an administrative transfer for which employers were fully compensated.

The success of moves to privatise pensions in the UK has also been paid for - through tax concessions and lower national insurance contributions - by taxpayers. These outcomes are the consequence of an aspect of privatisation which its proponents often ignore, the politics of the privatisation process itself and the impact of the relevant interest groups and stakeholders in the services being privatised. It is true that many privatisation proponents see increased reliance on market criteria as a means of ultimately avoiding the role of pressure groups. Yet in the process they pay insufficient attention to the way in which such groups can intervene in the policy process in order to which affect the form in which privatisation is eventually introduced and the effects to which it will ultimately give rise.

This discussion highlights the fact that the private (or non-government) sector in the welfare context encompasses the for-profit sector, the voluntary sector and the household sector. Each operates on quite different principles and it is misleading to consider them as equivalent in any meaningful sense. The only attribute they apparently share is their independence from

2 Australian experience with reforms in a range of areas, including tertiary student charges and child support, suggest that public finance of welfare provision has remained less impervious to change in Australia in the eighties than Le Grand claims has happened in Thatcher's Britain (Saunders, 1989). 
government, but even this is often not strictly the case, as our later discussion illustrates. In this expanded framework, the outcomes of the process of privatisation (as opposed to its initial aims) cannot always be clearly identified. The problem here is that privatisation tends to set in train its own dynamic which causes changes in other dimensions, as the UK experience just described clearly illustrates. What this suggests is that privatisation may change the form rather than the scope of government intervention, away from the more visible activities reflected in public budgets and towards tax concessions and increased regulatory activity which are less visible though potentially no less costly to the economy at large. Indeed, because existing accountability and control procedures apply more rigourously to direct outlays than to indirect forms of intervention, such a switch could result in a public sector which is not only less visible, but also less accountable, less controllable and more detrimental to economic efficiency and performance.

\section{Income Support}

There is no doubt that over the post-war period increased coverage of public pension schemes and higher benefits have been paramount in improving the relative economic position of the elderly. Poverty rates amongst the elderly have declined significantly over the last three decades in Australia as in most other OECD countries for which data are available (Saunders and Whiteford, 1987). Furthermore, differences in transfer income amongst the aged can explain a good deal of the observed cross-country differences in living standards, inequality and poverty (Hedstrom and Ringen, 1990). This is an area where the growth of the welfare state has been effective in achieving its aim of improving financial security and reducing vulnerability amongst a large and growing section of the community. The extent of government income support for the aged should not, however, be exaggerated. Not all of the elderly are pensioners, and most of those that are supplement their pension with other forms of income. Income support for the aged has thus had a private dimension in Australia for a very long time. This process has been accelerated in recent years by policy reforms like the assets test and the income deeming provisions for pensioners which have reduced pension eligibility and entitlement and increased the relative importance of private sources of income. 
An indication of the composition of income of the elderly and how it has changed over the last decade can be obtained from the income surveys conducted over the period by the Australian Bureau of Statistics (ABS). These provide details of the level and source of income for elderly income units - defined for these purposes to include single females aged 60 and over, single males aged 65 and over and couples headed by a male aged 65 or over. In summarising some of these data, we have aggregated total gross income into three broad categories; income from employment (wages and salaries and self employment income); income from accumulation (property income and superannuation benefits); and income from transfers (government cash benefits and a small residual component comprising other income in the form of workers' compensation, private transfers, and so on). ${ }^{3}$ The importance of these three elements in the total incomes of aged income units of different ages in 1981-82, 1985-86 and 1989-90 is shown in Table 1 .

The figures show that overall, transfer (mainly pension) income now accounts for less than half of the total income of the aged. Income from employment and from accumulation together account for over 53 per cent of total income, a contribution which has increased from around 44 per cent at the beginning of the eighties. The trend towards income support privatisation is thus apparent throughout the decade, although it has accelerated since 1985-86. Occupational superannuation has, to date at least, played only a minor role in this process, superannuation benefits increasing slightly in relative importance from 7.7 per cent of gross income in 1981-86 to 8.6 per cent of gross income in 1989-90. It should be noted, however, that the income surveys underlying Table 1 cover only regular income sources. This means that lump-sum superannuation payments are not part of income as defined, although they may be invested and earn interest, rent or dividend income.

The most important trend during the 1980 s has been the growing importance of property income, its contribution to gross income increasing from 28 per cent in 1981-82 to over 39 per cent by 1989-90. This, however, has not been a consequence of any conscious privatisation policy on the part of the

3 The residual element accounts for less than three per cent of total income in any category and generally less than one per cent. 
Table 1: Income Composition of Aged Income Units (Percentages of gross income)

\begin{tabular}{|c|c|c|c|c|c|c|c|c|c|}
\hline \multirow{3}{*}{$\begin{array}{l}\text { Age } \\
\text { Category }\end{array}$} & \multicolumn{3}{|c|}{ 1981-82 } & \multicolumn{3}{|c|}{$1985-86$} & \multicolumn{3}{|c|}{$1989-90$} \\
\hline & & Income source: & & & Income source: & & & Income source: & \\
\hline & Employment & Accumulation & Transfers & Employment & tt Accumulation & Transfers & Employment & it Accumulation & Transfers \\
\hline $60-64$ & 27.6 & 22.5 & 49.9 & 23.2 & 33.3 & 43.5 & 28.0 & 35.0 & 37.0 \\
\hline $65-69$ & 24.9 & 28.7 & 46.4 & 16.9 & 33.3 & 49.8 & 19.2 & 41.3 & 39.5 \\
\hline $70-74$ & 10.6 & 33.6 & 55.8 & 11.4 & 31.4 & 57.2 & 10.2 & 39.6 & 50.2 \\
\hline $75+$ & 6.7 & 24.9 & 68.4 & 3.6 & 37.9 & 58.5 & 7.6 & 38.1 & 53.4 \\
\hline All aged & 15.8 & 28.4 & 55.8 & 11.7 & 34.2 & 54.1 & 13.7 & 39.4 & 46.9 \\
\hline
\end{tabular}

Note: (a) Income from employment includes wages and salaries and self employment income Income from accumulation includes interest, rent and dividends and superannuation income. Transfer income is predominantly in the form of

Source: ABS Income Surveys for 1981-82, 1985-86 and 1989-90; unit record files. 
government, but largely a by-product of tight monetary policies and high interest rates. The result has apparently been income privatisation for the elderly, though that was hardly the motivation for what has happened. As interest rates decline this process will, of course, reverse itself, although the pension deeming provisions may complicate the adjustment somewhat.

Table 1 also shows income composition broken down by age, which allows the changing position of a synthetic cohort of the aged to be tracked through the $1980 \mathrm{~s}$ in terms of their income sources. This can be achieved by observing the changing incomes of those aged between 65 and 69 in 1981 82 , those in the 70-74 age group in 1985-86 and those aged 75 and over in 1989-90. These three groups are assumed to be representative of a single cohort of elderly people as they have aged during the decade. Changes in income composition for this cohort - illustrated by the figures in bold in Table 1 - show an increased role for transfer income between 1981-82 and 1989-90 (unlike the earlier cross-section comparisons which showed transfer income to be declining in importance). Again the most significant change is the growth in the relative size of income from accumulation generally, and from property income in particular. Additional analysis provides some evidence of a trend towards increased reliance on superannuation income among successive cohorts of the elderly. Superannuation accounted for 7.5 per cent of the income of those just retired (the 65-69 age group) in 1981-82,9.3 per cent of the income of this group in 1985-86 and 9.7 per cent of their income in 1989-90. These changes are not dramatic, but they are indicative of a trend which is likely to accelerate in future years as successive cohorts retire with superannuation coverage.

Both sides of politics regard pension privatisation through the encouragement of occupational superannuation as an appropriate longerterm policy response to population ageing. It is not possible to do justice to all of the issues here. Only a few salient points will be made. The first is that the switch to superannuation will be accompanied by significant changes in the form of government intervention. Pension spending will be reduced but the revenue cost of government tax concessions will rise, as will the degree and complexity of prudential and other regulation of private superannuation funds. The overall impact on government spending of expanding superannuation coverage will depend critically on the interaction between superannuation benefits and the pension income test. Presently, an 
aged couple with a private superannuation income of $\$ 200$ a week would have their pension reduced by only $\$ 63$ a week due to the operation of the pension income test. Whether pension savings of this order are justified by the tax concessions attached to superannuation is at least questionable. One way of improving this interaction might be to distinguish superannuation annuities (and income derived from superannation lump sums) from other income in the operation of the pension income test. Both the Government and Opposition recognise the need to limit the cost of the superannuation tax concessions, but face difficult political obstacles in achieving this. There is a real tightrope to be walked here, because the tax concessions have induced workers to accept lower wage increases in exchange for expanded superannuation coverage and benefits. This has understandably created a large (and growing) constituency who favour keeping the tax concessions in order both to maintain their current positions and to justify past wage outcomes.

But there is a more fundamental question hanging in the air over the entire superannuation issue. It relates to whether or not the underlying demographic changes can be any more easily handled by a funded retirement income system than by a pay-as-you-go (PAYG) general revenue financed system. The basic argument here is that our current PAYG system is vulnerable to population ageing because of fears that future generations of workers will not pay the taxes required to support an increasing number of retired people. In other words, the implicit inter-generational contract underlying PAYG schemes is not sustainable in the light of adverse demographic developments. In contrast, superannuation replaces (part of) the PAYG inter-generational contract with an intra-generational contract in the form of a life cycle savings scheme which allows (or requires) individuals to make savings whilst working in order to fund their retirement incomes.

The crucial point, however, is that the act of saving through such a funded pension scheme - as with virtually all other forms of saving - only provides people with a claim on a part of society's future resources. In order to actually exercise that claim, future generations of workers will still have to be persuaded to reduce their consumption in order that retirees can consume part of the output to which they are no longer contributing. Thus, even fully funded superannuation schemes do not avoid the need for an inter- 
generational contract regarding the division of total output between workers and the retired (Barr, 1979). A funded superannuation scheme - which essentially represents a different legislative expression of this intergenerational contract (one that is less explicit) - may thus be no more able to guarantee income levels for the elderly that are any more certain in the face of demographic change than those which will be forthcoming under the current PAYG pension system.

What is absolutely critical here is the extent to which the future level of output is dependent upon whether pension arrangements are organised on a PAYG or a funded basis. This in turn largely depends upon whether the shift to superannuation will cause the national savings rate to rise. If it does - and if these additional savings are put to productive use - then there is the potential for capital formation, productivity and economic growth to increase to an extent which can outweigh the projected adverse consequences of population ageing, as illustrated in a recent Brookings Study for the United States (Aaron, Bosworth and Burtless, 1989). The use to which these funds are put raises important issues relating to the control of the funds, who exercises that control, and the role of the government and other organisations in these decisions.

Currently, we simply do not know enough to have any confidence about what the overall impact of superannuation expansion on the national savings rate is likely to be. Nor can we be sure of the pattern of investments to which any increased saving will give rise. Certainly, there is evidence for countries like Japan, Sweden and Canada - where funded social security schemes have generated surpluses - that they have been used to expand capital formation and raise economic growth potential (Munnell and Ernsberger, 1989). In contrast, the United States has been noticeable in using its social security surpluses to finance the non-social security component of its budget deficit, in effect substituting public consumption for private consumption with no overall effect on national savings (Aaron, Bosworth and Burtless, 1989). As long as this can be avoided in Australia, and if savings do respond positively, the privatisation of pensions has the potential to improve economic performance in the medium term and meet the challenges of population ageing in the longer term. 


\section{Residential and Community Care}

As noted earlier, many aspects of the organisation of aged care services in Australia already combine public finance with private provision. In the case of nursing homes, services provided by both profit-making and non-profit organisations are funded directly by the Commonwealth government. For community support provided under the Home and Community Care Program (HACC), services are funded jointly by the Commonwealth and State governments and are provided by a range of independent, non-profit bodies, as well as by agencies auspiced by State and local government. Despite these differences, there are a number of characteristics common to both of these fields. Here, we briefly outline the postwar history of the current arrangements for the provision of nursing homes and community support services, before examining the rationale for the development of a pluralistic system of provisions in Australia, and the consequences or legacy that private control has left. ${ }^{4}$

\subsection{Nursing Homes}

The origins of the existing financial arrangements for both residential care and community support can be traced back to the first period of the Menzies Government in the early 1950s. Seeking to honour a promise that the Liberal/Country Party Government would: 'provide an effective bulwark against the socialisation of medicine' (Kewley, 1973: 507, cited in Sax, 1984: 60), the Commonwealth government instituted the Hospital Benefits Act of 1952, and a national system of voluntary health insurance in 1953, which had the effect of excluding many aged and disabled people from the hospitals on which they relied for long term care. For patients with chronic disabilities who were not able to be supported by their families, a series of somewhat ad hoc facilities developed. In some cases these were charitable homes established in properties owned and controlled by the churches. In others, service providers entered the field to make a profit, converting disused properties into 'rest homes' and 'convalescent homes'. State governments also used some of their large old benevolent asylums for

4 Hostel accommodation combines some of the characteristics of the finance and provision of both nursing homes and community support. Details of hostel provision, and many other aspects of aged care, are not discussed in this paper. 
similar purposes. Only a few of these, however, were eligible to receive funding in the form of Commonwealth hospital benefits (Sax, 1984).

According to Sidney Sax's account of the development of policy, changes to the Health Insurance Act, enacted in 1958, were necessary to enable benefits to be paid to people with what was considered to be a 'pre-existing medical condition' (Sax, 1984). But as these private health benefits were not payable in the bulk of the new 'convalescent homes' the arrangements proved both inequitable - rewarding only those fortunate enough to remain in a State run hospital - and inefficient - providing an incentive to keep those in need of long term care in the emerging acute hospital sector. To overcome these problems, a system of nursing home benefits was introduced in 1963 at the rate of 'a pound a person a day', or, as this became known after the introduction of decimal currency, $\$ 14$ per week.

The results of this open-ended commitment by the Commonwealth to subsidise non-government nursing homes are not hard to imagine. The number of nursing homes beds grew astronomically (Table 2), at a far greater rate than that of the aged population in general. The number of private, profit-making ventures grew particularly vigorously, as entrepreneurs, some of them 'matron owners', many of them medical practictioners, and others just sharp businessmen or women, realised the opportunity that a government guaranteed income provided. Their argument then, as now, was that the price at which they could provide a bed was well below that of the public sector. Many of the church run homes, however, claimed they were unable to provide services on such a tight budget. Consequently their rate of expansion was considerably lower, and in many of those church run homes which did operate, large deficits were incurred.

A series of minor reforms were made in the early $1970 \mathrm{~s}$, by both the Coalition Government under Gorton and McMahon and later the Whitlam Labor Government, to try to deal with some of these problems. Special 'deficit funding' arrangements were made for public funds to cover the deficits in the finance of non-profit homes, and, at the behest of the Australian Medical Association, medical controls were introduced over admissions (Sax, 1984). Interestingly, the rate of admission to nursing homes actually increased once the medical profession became the 
Table 2: Number of Nursing Home Beds in Australia, 1963-1990

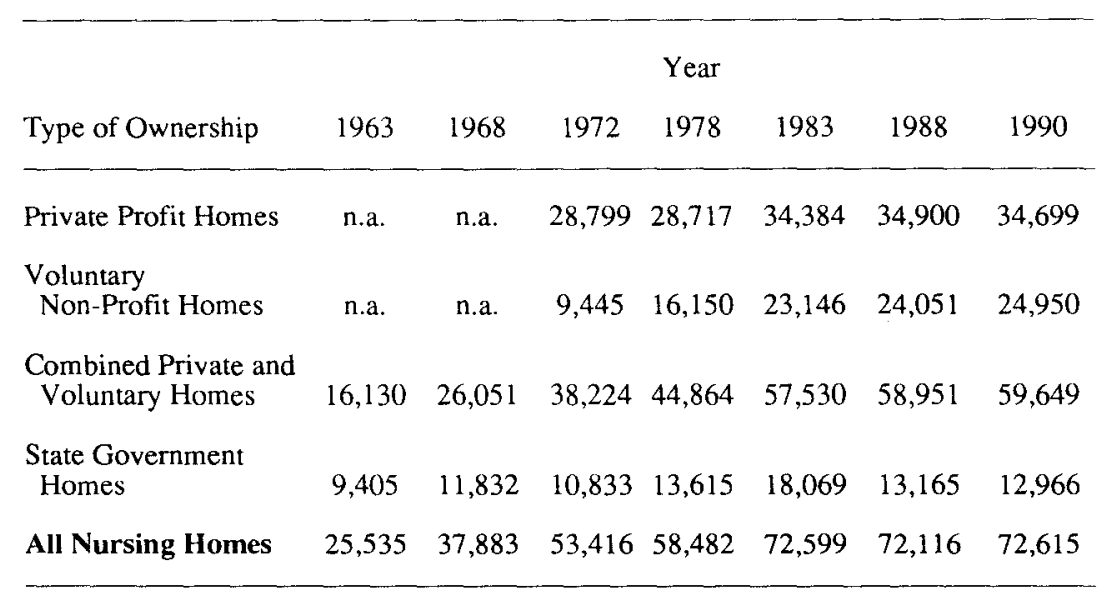

Source: Senate Select Committee (1984); DHHCS (1991).

gatekeepers. Commonwealth supervision over the process seemed incapable of tackling the problem arising from the power granted to these independent professionals. ${ }^{5}$ Driven by the apparently inexhaustible demand for places, the numbers of nursing home beds continued to grow, until, by the early 1980 s, Australia was said to have amongst the greatest number of nursing home beds per head of the aged population in the world (Department of Community Services, 1986). The level of expenditure required to maintain this stock of beds left little over for alternative forms of support, such as those provided by community support services. Many observers also noted the poor standards of care in many nursing homes, often linking these to problems in the payment of nursing home benefits and the reluctance of the Commonwealth government to take action (Senate Select Committee, 1984).

5 The Auditor General, in his report on the Commonwealth Administration of Nursing Home Programs, noted that only one of more than 137,000 admission applications completed by medical practitioners in New South Wales between 1973 and 1980 was rejected by Commonwealth officials (Auditor General, 1981: $58)$. 


\subsection{Community Support Services and the 'Balance of Care'}

Like nursing homes, community support services developed on a public finance - private provision model first introduced in the 1950s. The main difference was that the for-profit sector was virtually non-existent in community support services, most provision being undertaken by locallybased, non-profit, voluntary organisations. The first steps in the development of the system existing currently can be traced back to the Home Nursing Subsidy Scheme of 1957, under which the Commonwealth government paid the salary costs of all home nurses employed up to that date, and half the salary of all new home nurses employed afterwards. Other sources of funds for these services were grants from the State governments, and fees paid by patients (McLeay, 1982: 12). This model was elaborated in later devlopments, such as the States Grants (Home Care) and States Grants (Paramedical Services) Acts of 1969, which shared the costs of financing certain services between the Commonwealth and State governments. The Delivered Meals Subsidy Act of 1970, in contrast, involved a direct payment from the Commonwealth government to services operated by voluntary organisations and local government bodies.

If these schemes were intended to foster the development of community support services on a large scale, they proved inadequate in practice. As a number of government reports noted, the system of public finance which operated in the early 1980s had encouraged the provision of nursing home places, particularly the profit-making facilities, but had served to restrict the growth of services provided to people who remained in their own home. The mechanisms for public funding of community support services generally involved a complex, centralised and highly restrictive system in which a limited number of Commonwealth/State block grants were awarded on an annual basis to specific organisations. Because there was no direct link between the payments made to an organisation and the services provided to clients, this effectively limited the expansion of the system of community support (Fine, Graham and Webb, 1991). ${ }^{6}$ In contrast, nursing

6 The only exception to the system of block grants were the payments made to Meals on Wheels services. These payments, per delivered meal, were set at a low level. For example, in 1989 , the payment per meal was $\$ 0.65$, or $\$ 0.85$ if it contained a Vitamin C supplement, well below the estimated cost of provision. One of the assumptions behind the payment system was that Meals on Wheels services would remain reliant on assistance provided by volunteers. 
home funding was a routine payment for each patient per day, made to the nursing home proprietor which directly linked increases in finance to increases in provision, providing a major incentive for the expansion of the nursing home system.

The result was an imbalance in the system of care provision. Figures presented in the McLeay Report, for example, show that in the early eighties, for every one dollar spent by the Commonwealth on care at home, eleven dollars were spent on care in nursing homes or hostels (McLeay, 1982: 123). Even more important than the balance of expenditure between residential institutions and community support, however, was the fact that aged care represented a system in which the Commonwealth Government paid for, and was held responsible for, the system of services. Despite this, the Commonwealth did not exert effective control over the most significant elements of the system: the admission of patients to nursing home care and the overall level of provision of nursing home facilities. The system of payments was responsive to the apparently insatiable demand for nursing home assistance, but acted to restrict assistance provided for community support.

A number of reforms were introduced by the Labor Government in the mideighties to help overcome this situtation. The most important of these were:

- the introduction of planning measures for nursing home provision, effectively halting the continued expansion of nursing home bed numbers and setting a clear relationship between need, as reflected in demographic developments, and the supply of institutional facilities;

- the establishment of clear eligibility criteria and assessment procedures which reduced the rates of nursing home admission and linked the payments received by nursing home proprietors to the level of dependency of residents; and

- the introduction and development of the Home and Community Care Program (HACC), with costs shared by the Commonwealth and State governments, designed to provide an expanded range of services to people who require support to remain living independently in their own homes. 
These reforms had the effect of overcoming some of the imbalances in the system of aged care which previous funding regimes had seemed incapable of tackling. Indeed, the number of nursing homes and nursing home beds actually fell slightly between 1985 and 1991. This was achieved largely as a result of changes to the public funding mechanisms, with very few changes in the pattern of ownership and control of faciltites being required, apart from the mainly adminstrative transfer of voluntary homes away from the deficit financing arrangements developed in the mid-1970s. The savings on residential care funding enabled a modest increase in spending on community support services under the HACC Program (Table 3). As a result of these increases, the 'balance of care' between residential and community support swung dramatically in favour of the latter. Expenditure changed from more than $\$ 11.00$ spent on residential care for every dollar on community support in 1985 , to approximately $\$ 6.80$ for every dollar in 1990-91 (DHHCS, 1991). ${ }^{7}$

The reforms introduced in the mid-eighties were essentially based on the premise that the existing structure of aged care services would continue more or less as before. The structure continues today, as it developed in the $1950 \mathrm{~s}$ and $1960 \mathrm{~s}$, to be based on private control of publicly financed residential facilities, and the delivery of government funded support services by both non-government and State government agencies. Despite the rhetoric of many community groups and critics of the government, there have not been many systematic attempts to further privatise the provision of aged care under the current Labor Government, nor have there been any moves to significantly reverse the pre-existing order (Lyons, 1991). 8 This should, however, be seen against a background in which the private sector has long played a significant role in aged care provision, even if the for profit sector has not been as dominant in the field of community support as in the institutional area. The expansion of community support services

7 For an analysis of the change in Commonwealth expenditure on nursing homes in the context of the shift of resources towards community care, see Saunders (1989).

8 A notable exception is some elements of the Community Options Program discussed later in this paper. Some services are also provided in the home by commercial nursing agencies to people eligible for assistance through the Department of Veterans Affairs, which could also be regarded as evidence of the extension of market principles into the field of community support. 
Table 3: Commonwealth Aged Care Expenditure on Nursing Homes, Hostels and HACC, 1985-86 and 1990-91 (a)

\begin{tabular}{|c|c|c|c|c|c|}
\hline \multirow[t]{2}{*}{ Program area } & \multicolumn{2}{|c|}{$1985-86$} & \multicolumn{2}{|c|}{$1990-91$} & \multirow{2}{*}{$\begin{array}{c}\text { Increase } \\
\%\end{array}$} \\
\hline & $\$ \mathrm{~m}$ & $\%$ & $\$ \mathrm{~m}$ & $\%$ & \\
\hline \multicolumn{6}{|l|}{ Residential care } \\
\hline Nursing home benefits & 1429.9 & 81.0 & 1556.0 & 68.9 & 8.8 \\
\hline Hostel subsidies & 83.5 & 4.7 & 189.9 & 8.4 & 127.4 \\
\hline Special services $(b)$ & 0.6 & $*$ & 42.6 & 1.9 & $*$ \\
\hline User rights \& training & - & * & 2.6 & 0.1 & * \\
\hline Capital expenditure & 65.8 & 3.7 & 129.5 & 5.7 & 96.8 \\
\hline Sub Total & 1579.8 & 89.5 & 1900.6 & 85.0 & 20.3 \\
\hline $\mathrm{HACC}(\mathrm{c})$ & 142.8 & 8.1 & 278.9 & 12.4 & 95.3 \\
\hline $\operatorname{DNCB}^{(d)}$ & 36.0 & 2.0 & 33.0 & 1.5 & 8.3 \\
\hline Geriatric Assessment & 5.6 & 0.3 & 25.0 & 1.1 & 346.4 \\
\hline TOTAL & 1764.2 & 100.0 & 2257.5 & 100.0 & 28.0 \\
\hline
\end{tabular}

Notes: a) Figures are all in 1991 dollars.

b) Special services include dementia hostels grants, approved day care services and multi-purpose centres.

c) HACC figures include expenditure on the younger disabled.

d) Domicilary nursing care benefit

* Either no expenditure in 1985-86 or too small for calculating meaningful percentage increases.

Source: $\quad$ DHHCS, 1991: 40.

under the HACC Program has seen government funding of community support services rise sharply since since 1985 , with much of the increased funding directed to non-government service providing agencies. This process has been accompanied by increased regulation of such agencies, as government has tried to exercise accountability for its funds in the shortterm and to maintain control over resource planning in the medium-term. 


\subsection{The Underlying Causes of 'Welfare Pluralism' in Australian Aged Care}

A continuing theme in the development of aged care services has been the reliance by the Commonwealth Government on a diverse mix of service providers. Part of the reason for this was ideological. In the cold war period the Liberal/Country party took a strong stance against nationalised control of any part of the economy. Their alliance with the medical profession in its opposition to a national health system was also very significant. There were, however, a number of other non-ideological reasons for the adoption and continuation of such an approach. For many years, non-government initiatives set the pace, as it were, establishing patterns of service to which the Commonwealth Government only belatedly responded. The churches and private nursing home proprietors were particularly successful in this regard, identifying a need and moving to fill the market niche for long term residential care as a result of changes in the use of hospitals in the postwar period. Their ability to put pressure on the govemment for subsidies contrasted with the absence of demands from trade unions and other social activists for an alternative approach (Sax, 1984).

Adding to the political complexity of these moves have been the provisions of the Australian Constitution, under which State governments have responsibility for health and welfare services, although the Commonwealth has far greater powers of revenue collection. Direct payment to the States of monies for aged care would have seen the Commonwealth Government effectively lose control, both of the uses to which those funds were being put and, more importantly, of the policy reform agenda. Some have argued that under such a system, the States would have used the money within the existing system of hospital services, with little, if nothing extra in the field of aged care to show for the Commonwealth's effort. The direct funding of non-govemment agencies by the Commonwealth, and, in the field of community support, the sharing of costs with State governments, overcomes some, if not all of these constitutional problems.

The adoption of elements of this model of government finance and mixed private and public provision in community support also owed much to the capacity of the Commonwealth to simultaneously restrict expenditure on services, while offering patronage to local groups through the award of 
grants. This approach was by no means restricted to one side of politics. The enthusiasm of the Whitlam and later Hawke Governments for making direct grants to so - called 'community groups' under respectively, the Australian Assistance Program and the HACC program, is well recognised, and it has undoubtedly contributed to the development and maintenance of a system of services outside the direct control of government.

One clear difference between the two main parties in the past, however, has been the reluctance of Labor politicians to seek to patronise private, profitmaking, entrepreneurs as providers of aged care. The preferential treatment of voluntary organisations under the deficit funding arrangements operating between 1975 and 1985 was one of the main factors behind the relatively high rate of growth of this sector of the nursing home industry during this period (Parker, 1987). The ALP's preference for the non-profit homes did not, however, endure. Some members of the caucus may have been disturbed by the McLeay Reports' revelations that clients who made substantial donations on entry gained preferential access to many of the nonprofit beds, with the result that the less affluent were more likely to have to rely on the private profit facilitites (McLeay, 1982). Others were no doubt aware of other funding problems, such as the 'extensive care' benefit which, it was claimed, provided an incentive to proprietors to keep patients bedbound (Auditor General, 1981; McLeay, 1982) Certainly, the desire of the Hawke Government to reform the system of nursing home funding has led to a number of reforms in recent years, including the abolition of the deficit-funding arrangements in favour of a single funding regime for 'participating' nursing homes (DHHCS, 1991a).

The HACC Program is another example of Labor initiatives in this field which has attempted to ensure that direct grants are provided only to nonprofit agencies (DCSH, 1988). Yet here too there is evidence of a softening of this approach in recent years. Most significant of these for the long term has been the introduction of the Community Options and Hostel Options Programs, which provide case managers with a separate budget with which to purchase services for each client. While it would be fair to say that the use of for-profit services has been tolerated rather than encouraged by the Labor government, it is clear that a principled and ideological approach against profit in the field of aged care is giving way to a rather more 
pragmatic view of a hard headed working relationship with whoever it is that can deliver services on a most cost effective basis.

The mechanisms of public funding have also been an important determinant of the development of aged care services in Australia. The effect of the different forms of grants in the nursing home and community support sectors has already been mentioned. A related issue concerns the distinction between capital and recurrent funding paid by the Commonwealth government for the provision of nursing homes. One of the main advantages for the Commonwealth Government of using a range of private providers in the nursing home field has been their ability to raise their own capital. The ease with which such funds could be raised by private entrepreneurs, where necessary using borrowed funds, may in fact explain the apparently rapid growth of these homes in the 1950s, before Commmonwealth funding, and in the 1960s and 1970s, following the introduction of national subsidies. In the case of the for-profit homes, the Commonwealth's input in any one year was therefore restricted to recurrent expenditures. It is clear that, at least until recent years, such homes have been cheaper per bed, than government-run alternatives. The payment of recurrent costs by the Commonwealth while less costly in the short run, provided an incentive to all private operators of nursing homes to expand beyond the limits of national efficiency.

\subsection{Other Consequences of the System of Finance, Ownership and Control}

This account of policy development has concentrated on the effects of the system of funding and provision on the growth of services and the implications this has had for Commonwealth control of expenditure in the field of aged care. Problems with the coordination of services and service quality assurance have been equally contentious issues. The large number of different service providers involved is one of the main consequences of the separation of finance from provision under the Australian system described above. Indeed, it can be argued that many of the difficulties of coordination encountered in the provision of assistance and the fragmentation evident in the system of referral and assessment which seem endemic to the provision of aged care in Australia, arise directly from the 
system of centralised funding of autonomous local services (Fine, Graham and Webb, 1991).

The multiplicity of management structures, each with its own set of decision-making mechanisms and procedures, has also made it difficult, if not impossible, for the Commonwealth or State governments to exercise control over the standards of direct provision of assistance to individuals. In recent years, attempts to ensure that a minimum standard of quality is maintained have focused on what is generally referred to as 'users' rights'. In the field of nursing home care, this has seen a system of outcome standards introduced, backed up by a system of inspection, and the introduction of legal contracts between proprietors and residents. These moves have been resisted by mangement and proprietors, both those from the private profit facilities and those from non-profit services, who have accused the Commonwealth Government of attempting to shift the blame for inadequate funding. In the field of community support, however, little of substance has been achieved to date, despite the widespread recognition of shortcomings in this aspect of the HACC program (HACC Review, 1989; Auditor General, 1988). The earlier comments on the role of user charges policies as a means of enhancing user rights has not been given serious consideration at the policy level. Where user charges have been discussed, they have been seen as a means of supplementing the funding of services or, through grant offsets, reducing government expenditure, rather than as a means of enhancing user rights

\section{Conclusions}

In this paper we have attempted to show how simplified approaches to privatisation provide an inadequate framework for analysing the complex mix of finance and provision involved in support policies for the aged in Australia. Nonetheless, our description of past policy development and analysis of some of its consequences provides little comfort for those who see privatisation as sure-fire means of cutting costs, increasing efficiency and expanding choice. A critical point to understand is that the process of privatisation inevitably exposes policy development to interest group politics which can divert the aims of the policy, often at a cost to the public 
purse. There are already a number of examples in Australia and elsehwere to support this view, many of them in the aged care field.

In the income support field the privatisation of pensions through superannuation is already well underway and can no longer be reversed without enormous economic and social costs and attendant political risks. The projected reductions in the pension bill are, however, likely to be accompanied by the higher cost of superannuation tax concessions and by increased regulation of superannuation funds. The extent to which such moves will ease the adjustment to an ageing population is debatable, the issue revolving critically around the impact of superannuation expansion on national savings, the uses to which such increased savings are put, and the impact they will have on the pace of economic development.

In the aged care field, the general trend throughout the $1980 \mathrm{~s}$ has been for the government to seek to assert greater control over private institutional and community service providers who have long been the dominant forms of service provision and delivery, albeit largely publicly funded. It is difficult to present hard evidence of increased privatisation in either area in the last decade or so, despite the rhetoric and concerns expressed by those involved in the field. Indeed, the trend towards increased government control suggests something of a trend away from the previous extremes of privatisation, at least in some dimensions of government activity. Certainly, past experience in the field of aged support policies provides evidence that privatisation offers no universal cure to the problems with which the Australian welfare state has been grappling for some considerable time.

\section{References}

Aaron, J. J., B. P. Bosworth and G. Burtless (1989), Can America Afford to Grow Old?, The Brookings Institution, Washington DC.

Auditor General (1981), Commonwealth Administration of Nursing Home Programs. Report of the Auditor General on an Efficiency Audit, AGPS, Canberra.

Barr, N. A. (1979), 'Myths my grandpa taught me', The Three Banks Review, 124, December, 27-55.

Bradshaw, J. (1991), 'Social security', in D. Marsh and R. A. W. Rhodes, eds, Implementing Thatcherite Policies. Audit of an Era, Open University Press, Buckingham, England. 
Cox, J. (1992a), 'Microeconomic reform and the welfare state', Policy, 8, Autumn, 11-14.

Cox, J. (1992b), Private Welfare, The Centre for Independent Studies, Sydney.

Department of Community Services (1986), Nursing Homes and Hostels Review, AGPS, Canberra.

Department of Community Services and Health (DCS\&H) (1988), Home and Community Care Program. National Guidelines, Canberra.

Department of Health Housing and Community Services (DHH\&CS) (1991), Aged Care Reform Strategy Mid Term Review 1990-91, AGPS, Canberra.

Department of Health Housing and Community Services (1992), It's Your Choice: a report outlining the development of the Community Options initiative and drawing together the findings of State and Territory project evaluations, Home and Community Care Branch, Aged and Community Care Division, AGPS, Canberra.

Fine, M. (1992), Community Support Services and Their Users. The First Eighteen Months, SPRC Reports and Proceedings No. 100, Social Policy Research Centre, University of New South Wales, Kensington.

Fine, M., S. Graham, and A. Webb (1991), Benchmarks and Other Approaches to Planning Community Support Services: A Review of International Experience, SPRC Reports and Proceedings No. 94, Social Policy Research Centre, University of New South Wales, Kensington.

First Triennial Review of the Home and Community Care Program (the HACC Review) (1989), AGPS, Carberra.

Graham, S., R. Ross, and T. Payne (1991), The Evaluation of Community Options in New South Wales. Final Report, SPRC Reports and Proceedings No. 103, Social Policy Research Centre, University of New South Wales, Kensington.

Hedstrom, P. and S. Ringen (1990), 'Age and income in contemporary society' in T. Smeeding, M. O'Higgins and L. Rainwater, eds, Poverty, Inequality and Income Distribution in Comparative Perspective. The Luxembourg Income Study, Harvester Wheatsheaf, London, 77-104.

Klein, R. (1984), 'Privatisation and the welfare state', Lloyds Bank Review, January, 12-29.

Le Grand, J. (1990), 'The state of welfare', in J. Hills, ed., The State of Welfare. The Welfare State in Britain Since 1974, Oxford University Press, 338-60.

Le Grand, J. (1991), 'Quasi-markets and social policy' Economic Journal, 101, 1256-67.

Le Grand, J. (1992), 'Paying For or Providing Welfare?', presented to the British Social Policy Association Annual Conference, University of Nottingham, July. 
Le Grand, J. and R. Robinson (1984), 'Privatisation and the welfare state: an introduction', in J. Le Grand and R. Robinson, eds, Privatisation and the Welfare State, George Allen and Unwin, London, 1-8.

Lyons, M. (1991), The Privatisation of Human Services in Australia: Myth and Reality, CACOM Working Paper No. 5, Centre for Australian Community Organisations and Management, University of Technology, Sydney.

McLeay, L. (Chairperson) (1982), In a Home or At Home: Accommodation and Home Care for the Aged, Report from the House of Representatives Standing Committee on Expenditure, AGPS, Canberra.

Munnell, A. H. and C. N. Ernsberger (1989), 'Public pension surpluses and national saving: foreign experience', New England Economic Review, March/April, 16-38.

O'Connor, P. (1990), 'Privatisation and welfare services', Australian Journal of Social Issues, 25 (1), February, 27-39.

O'Higgins, M. (1981), 'Income during initial sickness: an analysis and evaluation of a new strategy for social security', Policy and Politics, 9(2), 151-71.

Parker, R. A. (1987), The Elderly and Residential Care. Australian Lessons for Britain, Gower Aldershot.

Saunders, P. (1989), Towards an Understanding of Commonwealth Social Expenditure Trends, SPRC Discussion Paper No. 16, Social Policy Research Centre, University of New South Wales, Kensington.

Saunders, P. (1992), 'Recent trends in the size and growth of government in OECD countries' in N. Gemmell, ed., The Growth of the Public Sector. Theories and International Evidence, Edward Elgar, Cheltenham.

Saunders, P. and P. Whiteford (1987), Ending Child Poverty. An Assessment of the Government's Family Package, SWRC Reports and Proceedings No. 69, Social Policy Research Centre, University of New South Wales, Kensington.

Sax, S. (1984), A Strife of Interests. Politics and Policies of Australian Health Services, George Allen and Unwin, Sydney.

Senate Select Committee (1984), Private Nursing Homes in Australia: Their Conduct, Administration and Ownership, Report by the Senate Select Committee on Private Hospitals and Nursing Homes, AGPS, Canberra.

Walker, A. (1984), 'The political economy of privatisation', in Le Grand and Robinson, eds, Privatisation and the Welfare State, George Allen and Unwin, London, 19-44. 
SOCIAL POLICY RESEARCH CENTRE DISCUSSION PAPERS:

$+\quad$ No longer available.

1. The Labour Market Position of Aboriginal People in Non-Metropolitan New South Wales

Russell Ross

August 1988

2. Welfare Fraud, Work Incentives and Income Support for the Unemployed

3. Taxation and Social Security: An Overview

4. Income Inequality in Australia in an International Comparative Perspective

5. Family Size Equivalence Scales and Survey Evaluations of Income and Well-Being

$6^{\star}$ Income Testing the Tax Threshold

7. ${ }^{\uparrow}$ Workers' Compensation and Social Security Expenditure in Australia: Anti-Social Aspects of the 'Social' Wage

8. Teenagers in the Labour Market: $1983-1988$

9. A Legacy of Choice: Economic Thought and Social Policy in Australia, the Early Post-War Years

10. The 'Family Package' and the Cost of Children

11. Towards an Understanding of Commonwealth Social Expenditure Trends

12. A Comparative Study of Home and Hospital Births: Scientific and Normative Variables and their Effects

13. Adult Goods and the Cost of Children in Australia

14. ${ }^{\dagger}$ Some Australian Evidence on the Consensual Approach to Poverty Measurement

15. Income Inequality in Australia and New Zealand: International Comparisons and Recent Trends

$16^{+}$Trends in the Disposable Incomes of Australian Families, 1982-83 to 1989-90

17. Selectivity and Targeting in Income Support: The Australian Experience

Bruce Bradbury

August 1988

Peter Whiteford

August 1988

Peter Saunders \&

August 1988

Garry Hobbes

Bruce Bradbury

December 1988

Peter Whiteford

December 1988

Don Stewart \&

December 1988

Jennifer Doyle

Russell Ross

December 1988

Paul Smyth

May 1989

Bruce Bradbury

May 1989

Peter Saunders

May 1989

Cathy Boland

July 1989

Bruce Bradbury

July 1989

Peter Saunders \&

July 1989 Bruce Bradbury

Peter Saunders, Garry Hobbes \& September 1989 Helen Stott

Bruce Bradbury, Jennifer Doyle \& Peter Whiteford

January 1990

Peter Saunders

February 1990 
18. How Reliable are Estimates of Poverty in Australia? Some Sensitivity Tests for the Period 1981-82 to 1985-86

19. The Labour Supply Behaviour of Single Mothers and Married Mothers in Australia

20. Income Poverty Among Aboriginal Families with Children: Estimates from the 1986 Census

21. Compensating Low Income Groups for Indirect Tax Reforms

22. Reflections on the Review of the Home and Community Care Program

23. Sole Parent Families in Australia

24. ${ }^{\dagger}$ Unemployment, Participation and Family Incomes in the 1980s

25. Employment Growth and Poverty: An Analysis of Australian Experience, 1983-1990

26. Gender, Social Policy Regimes and the Welfare State

27. A Probit Analysis of the Factors Influencing Labour Market Success of Aborigines in New South Wales

28. Efficiency and Effectiveness in Social Policies: An International Perspective

29. Take-up of Family Income Supplement in 1986 A Research Note

30. An Ever-Rising Tide? Poverty in Australia in the Eighties:

31. Are Immigrants Over-Represented in the Australian Social Security System?

32. Measuring the Cost of Children

33. The Impact of Family Assistance Changes on Patterns of Unemployment Benefit Receipt

34. Recent Trends in the Size and Growth of Government in OECD Countries

35. Noncash Income, Living Standards, Inequality and Poverty: Evidence from the Luxembourg Income Study

36. The Mixed Economy of Support for the Aged In Australia: Lesson for Privatisation
Bruce Bradbury \& February 1990 Peter Saunders

Russell Ross \& Peter Saunders

July 1990

Russell Ross \&

Peter Whiteford

July 1990

Peter Saunders \& Peter Whiteford

Peter Saunders

August 1990

August 1990

Peter Saunders \& September 1990 George Matheson

Bruce Bradbury

September 1990

Peter Saunders

September 1990

Sheila Shaver

November 1990

Russell Ross

November 1990

Peter Saunders

December 1990

Peter Whiteford \& February 1991 Jennifer Doyle

Peter Saunders \& $\quad$ May 1991 George Matheson

Peter Whiteford

March 1992

Bruce Bradbury

May 1992

Bruce Bradbury

August 1992

Peter Saunders

September 1992

Peter Saunders et al.

November 1992

Peter Saunders \& Michael Fine 